\title{
CORRELATES OF ADOPTION OF COMPOSITE FISH CULTURE PRACTICES BY FISH FARMERS OF ASSAM, INDIA
}

\author{
P.K.Talukdar ${ }^{1}$ and B. S. Sontaki ${ }^{2}$
}

\begin{abstract}
The present study carried out during 1999 - 2000 in the purposively selected Sonitpur district of Assam focused on the factors influencing adoption of composite fish culture practices by the fish farmers. The data were gathered using a structured and pre-tested interview schedule from 60 randomly selected fish farmers. The findings revealed that majority (63\%) of fish farmers belonged to medium category of adoption. The adoption behaviour of composite fish culture practices was positively influenced by the factors like extension participation, economic motivation, cosmopoliteness, scientific orientation and knowledge of fish farmers, and negatively by their age. In view of the above findings, the study recommends that efforts should be made by extension agencies through their various programmes to highlight the economic benefits of composite fish farming to promote large-scale adoption of this technology. Study tours, exposure visits, participation in fairs and exhibitions could be the ideal methods for promoting adoption of composite fish culture.
\end{abstract}

\section{INTRODUCTION}

Assam is rich in fishery resources in the form of beels, rivers, ponds, tanks, forest fisheries, swamps, wetland, reservoirs and paddy fields. From the time immemorial fish has played an important role in social customs and traditions of the people in Assam. Fish being one of the main food items for about $95 \%$ of population of Assam, the demand for fish is very high in the state. The present annual fish production from all sources is about 1.55 lakh tons, against the requirement of fish for the state per year of 2.50 lakh tons, calculated on the basis of average per capita nutritional requirement. Thus there is a wide gap in between supply and demand. The demand of fish is expected to be 3.20 lakh tons by 2000 AD (Anon 1996).

Polyculture of indigenous and exotic carps is popularly known as Composite Fish Culture (CFC). It involves stocking and growing two or more compatible and complimentary fish species like Indian Major Carps (IMCs), Chinese Carps and the Common Carp in a waterbody like pond to maximize fish production by fullest utilization of all available niches in the pond ecosystem. The principle behind the $\mathrm{CFC}$ is to produce maximum quantity of fish per unit area from a scientifically managed water body by stocking fast growing, economically important, compatible species having shortest food chain utilizing the all ecological niches of the water body. Even though composite fish culture is an age-old practice in India and the area studied, the level of knowledge and extent of adoption of this technology by fish farmers of Assam is not known. In fact, hardly any systematic research has gone in to explore these areas. Keeping in view the dearth of such studies especially in Assam, the present study was undertaken with the following objectives:

- to study the extent of adoption of composite fish culture practices by fish farmers and

- to identify the factors influencing adoption of composite fish culture practices by fish farmers.

\section{MATERIALS AND METHODS}

The present study was carried out using ex-post-facto research design during 19992000 in the purposively selected Sonitpur district of Assam. A combination of purposive and systematic random sampling procedures was employed to select the district and block, villages and respondents. Out of the 23 districts in Assam, Sonitpur district was purposively

${ }^{1}$ Fisheries Extension Officer, Department of Fisheries, Government of Assam, India

${ }^{2}$ Senior Scientist \& Faculty, National Academy of Agricultural Research Management, Rajendranagar,

Hyderabad - 500030 (Andhra Pradesh, India). 
selected as it has vast and diverse inland fishery resources ideally suited for taking up composite fish culture. The block with maximum number of fish farmers practicing composite fish culture, i.e., Gabharu block was selected for the study. A list of villages of Gabharu development block with the number of fish farmers practicing composite fish culture in each village was obtained from the Fishery Extension Officer of the block. From this list, ten villages with a minimum of 15 fish farmers practising composite fish culture were selected for the study. Sixty fish farmers comprising six from each selected village constituted the respondents for the study.

The dependent variable, extent of adoption of composite fish culture practices, was quantified by using the scale developed by Singh (1992). Based on a thorough review of relevant literature and discussion with the experts in the subject, a total of 13 independent variables having some bearing on the dependent variable were identified for inclusion in the study. These independent variables represented personal, socio-economic and psychological characteristics of the respondents and were empirically measured by procedures evolved for the purpose and also by using scales and scoring procedures developed by earlier researchers. Study variables, their operational definitions and measurement procedures are given in Table 01. A structured and pre-tested interview schedule was used to collect data from the respondents by personal interview method.

\section{RESULTS AND DISCUSSION}

The distribution of respondents based on their level of adoption of composite fish culture practices is shown in Table 01 . Majority of the respondents (63\%) belonged to 'medium' category followed by $20 \%$ and $17.00 \%$ in 'high' and 'low' categories of adoption of composite fish culture practices, respectively. Thus, it implied that majority of the farmers of Sonitpur district of Assam are adopting the composite fish culture technology to medium extent, which might be due to the reason that most of the farmers have correct knowledge about many of the simple and basic practices of composite fish culture. Although this is an encouraging trend, efforts are still required to promote large-scale adoption of this technology. This finding is in conformity with the results reported by Mahandrakumar (1996).

Zero order correlation analysis was carried out between selected personal, socioeconomic and psychological characteristics of fish farmers and their extent of adoption (Table 02). A perusal of Table 02 shows that only four factors viz., extension participation, economic motivation, cosmopoliteness and scientific orientation positively influenced the adoption behaviour of fish farmers. Age showed negative influence. The other factors studied like experience in composite fish culture, size of the pond, total annual income, social participation, extension contact, risk preference and attitude did not influence adoption behaviour of fish farmers to a significant level. These results imply that high adopters of composite fish culture practices could be characterized by their young age and higher levels of extension participation, economic motivation, cosmopoliteness and scientific orientation.

It is obvious that younger farmers being more enthusiastic are attracted more towards scientific technologies. Hence the younger respondents adopted more practices. This finding is similar to those of Mahandrakumar (1996).

Extension participation showed positively significant relationship with adoption of composite fish culture implying thereby that farmers with more participation in extension activities have higher adoption and vice versa. Participation in extension activities contributes in more than one way. It helps to broaden the knowledge. It also gives a chance to learn about the various benefits like training, credit, subsidy, etc. All these are important in adopting technologies. The economic motivation of farmers was positively and significantly related to extent of adoption 
Table 01. Study variables, their operational definitions and measurement procedures

\begin{tabular}{|c|c|c|c|}
\hline $\begin{array}{l}\text { Sr. } \\
\text { No. }\end{array}$ & Variable & Operational Definition & $\begin{array}{l}\text { Measurement } \\
\text { Procedure }\end{array}$ \\
\hline \multicolumn{4}{|c|}{ A. Dependent Variable } \\
\hline 1. & $\begin{array}{l}\text { Adoption of } \\
\text { Composite Fish } \\
\text { Culture practices }\end{array}$ & $\begin{array}{l}\text { Extent to which a respondent put into practice } \\
\text { the recommended packages of CFC as the best } \\
\text { course of action in order to increase fish } \\
\text { production }\end{array}$ & Singh (1992) \\
\hline \multicolumn{4}{|c|}{ B. Independent Variables } \\
\hline 2. & Age & $\begin{array}{l}\text { Chronological age in number of completed } \\
\text { years by the respondent at the time of interview }\end{array}$ & $\begin{array}{l}\text { Procedure } \\
\text { developed }\end{array}$ \\
\hline 3 & Education & $\begin{array}{l}\text { Level of formal education of the respondents in } \\
\text { terms of formal schooling }\end{array}$ & $\begin{array}{l}\text { Sontakki } \\
(1989)\end{array}$ \\
\hline 4 & Experience & $\begin{array}{l}\text { Number of years for which a respondent has } \\
\text { been practising CFC at the time of inquiry }\end{array}$ & $\begin{array}{l}\text { Procedure } \\
\text { developed }\end{array}$ \\
\hline 5 & Pond Size & $\begin{array}{l}\text { Extent of water area (in hectare) used for CFC } \\
\text { by a respondent }\end{array}$ & $\begin{array}{l}\text { Procedure } \\
\text { developed }\end{array}$ \\
\hline 6 & $\begin{array}{l}\text { Total } \\
\text { Income }\end{array}$ & $\begin{array}{l}\text { Total earnings (in rupees) of the respondent in } \\
\text { a year from all sources including } \\
\text { CFC/aquaculture. }\end{array}$ & $\begin{array}{l}\text { Procedure } \\
\text { developed }\end{array}$ \\
\hline 7 & $\begin{array}{l}\text { Social } \\
\text { Participation }\end{array}$ & $\begin{array}{l}\text { Extent to which a respondent participated in the } \\
\text { activities of formal social organizations as } \\
\text { member or office bearer during past five years. }\end{array}$ & Trivedi (1963) \\
\hline 8 & Extension Contact & $\begin{array}{l}\text { Frequency of contact of a respondent with any } \\
\text { personnel of the various extension agencies to } \\
\text { get information on CFC }\end{array}$ & $\begin{array}{l}\text { Bhaskaran } \\
\text { (1976) }\end{array}$ \\
\hline 9 & $\begin{array}{l}\text { Extension } \\
\text { Participation }\end{array}$ & $\begin{array}{l}\text { Degree to which a respondent participated in } \\
\text { various non-formal educational activities } \\
\text { including individual contact, group contact and } \\
\text { mass contact methods to obtain information on } \\
\text { CFC }\end{array}$ & $\begin{array}{l}\text { Siddaramaiah } \\
\text { and Jalihal } \\
\text { (1983) }\end{array}$ \\
\hline 10 & $\begin{array}{l}\text { Economic } \\
\text { Motivation }\end{array}$ & $\begin{array}{l}\text { Degree to which a respondent accepted } \mathrm{CFC} \text { as } \\
\text { a viable occupation in terms of maximum } \\
\text { profit. }\end{array}$ & $\begin{array}{l}\text { Supe and Singh } \\
(1969) \text {. }\end{array}$ \\
\hline 11 & $\begin{array}{l}\text { Scientific } \\
\text { Orientation }\end{array}$ & $\begin{array}{l}\text { Degree of respondent's orientation towards the } \\
\text { scientific technique of CFC }\end{array}$ & $\begin{array}{l}\text { Supe and Singh } \\
(1969) \text {. }\end{array}$ \\
\hline 12 & Risk Preference & $\begin{array}{l}\text { Degree of respondent's orientation towards the } \\
\text { risk and uncertainties involved in CFC }\end{array}$ & $\begin{array}{l}\text { Supe and Singh } \\
(1969) .\end{array}$ \\
\hline 13 & Cosmopoliteness & $\begin{array}{l}\text { Degree of use of sources outside his own } \\
\text { community to meet information needs on CFC }\end{array}$ & Singh (1964) \\
\hline 14 & Attitude & $\begin{array}{l}\text { Degree of positive and negative affect of } \\
\text { respondent associated with CFC }\end{array}$ & Haque (1987) \\
\hline 15 & Knowledge & $\begin{array}{l}\text { The body of understood information on CFC } \\
\text { by the respondents }\end{array}$ & Haque (1987) \\
\hline
\end{tabular}


Table 02. Distribution of respondents based on their level of adoption of composite fish culture.

\begin{tabular}{cccc}
\hline & & $(\mathrm{n}=60)$ \\
\hline \multicolumn{2}{c}{ Adoption categories } & Frequency $(\mathbf{F})$ & Percentage (\%) \\
\hline Low & $(<16)$ & 10 & 16.66 \\
Medium & $(16-24)$ & 38 & 63.33 \\
High & $(>24)$ & 12 & 20.00 \\
\hline
\end{tabular}

Mean $=20.8833 \quad \mathrm{SD}=4.3324$

Table 03. Relationship between selected personal socioeconomic and communication of respondents and their knowledge level and extent of adoption of composite fish culture practices.

\begin{tabular}{|c|c|c|}
\hline Sl. No. & Variables & $\begin{aligned}(\mathrm{n}=6 \\
\text { "r" values }\end{aligned}$ \\
\hline 1. & Age & $-0.2948 *$ \\
\hline 2. & Education & $0.2377^{\mathrm{NS}}$ \\
\hline 3. & Experience in composite fish culture & $-0.0527^{\mathrm{NS}}$ \\
\hline 4. & Size of the pond & $0.1038^{\mathrm{NS}}$ \\
\hline 5. & Total annual income & $0.2368^{\mathrm{NS}}$ \\
\hline 6. & Social participation & $-0.0196^{\mathrm{NS}}$ \\
\hline 7. & Extension contact & $0.1846^{\mathrm{NS}}$ \\
\hline 8. & Extension participation & $0.5419 * *$ \\
\hline 9. & Economic motivation & $0.4924 * *$ \\
\hline 10. & Scientific orientation & $0.3215^{*}$ \\
\hline 11. & Risk preference & $0.2407^{\mathrm{NS}}$ \\
\hline 12. & Cosmopoliteness & $0.3937 * *$ \\
\hline 13. & Attitude towards composite fish culture & $-0.0114^{\mathrm{NS}}$ \\
\hline 14. & Knowledge of composite fish culture & $0.6016^{*}$ \\
\hline
\end{tabular}

NS - Non Significant

- - Significant at $1 \%$ level of significance

- $\quad * *$ - Significant at 5\% level of significancescience and technology in their occupation have more adoption. This finding is in line with those of Meeran (1983), Bose, (1989), Praveen (1993) and Mahandrakumar (1996). 
of composite fish culture practices. It, therefore, implies that those farmers, who have a tendency to maximize their earnings and strive towards this end, have higher adoption. This research finding is line with the findings of Haque (1979), Haque and Ray (1983), Haque and Ray (1985), Bose (1989), Biswas et al. (1991), Praveen (1993) and Mahandrakumar (1996).

The cosmopoliteness of farmers shows significantly positive relationship with adoption of composite fish culture practices, implying thereby that those farmers with higher contacts beyond their own social system, have more adoption. This finding corroborates those of Haque (1979), Das et al. (1987), Praveen (1993) and Mahandrakumar (1996).

The scientific orientation of respondents showed positive and significant relationship with the extent of adoption. In other words, the farmers with greater orientation towards application of science and technology in their occupation have more adoption. This finding is in line with those of Meeran (1983), Bose, (1989), Praveen (1993) and Mahandrakumar (1996).

Although the other variables like education, experience in composite fish culture, size of the pond, total annual income, social participation, extension contact, risk preference and attitude are generally supposed to be important in influencing the adoption behaviour of farmers, the relationship could not be established in the present study. This could, perhaps, be due to lack of sufficient variation in these variables to cause significant change in the dependent variable, i.e., extent of adoption, as it was observed in the study that a large majority of the fish farmers were distributed in medium categories in respect of all these variables.

It could be observed from Table 03 that the knowledge level of respondents on composite fish culture is positively and significantly correlated to their extent of adoption as indicated by significant ${ }^{\prime} \mathrm{r}$ ' value (0.6016). It means that when the knowledge of respondents regarding composite fish culture practices is more the extent of adoption of composite fish culture is also more. This finding is in line with those of Haque (1979), Ghosh, et. al. (1993) and Mahandrakumar (1996). Diffusion research studies conducted over the past four decades or so have already established a positive relation between knowledge and adoption (Rogers, 1987). The finding of the study, thus, corroborates this trend.

\section{CONCLUSIONS}

The study revealed that majority of the respondent fish farmers adopted the recommended technologies of CFC to medium extent. The factors like extension participation, economic motivation, cosmopoliteness, scientific orientation and knowledge of CFC exhibited positive influence while age showed negative influence on the adoption of composite fish culture practices by fish farmers. Based on the above findings the study recommends the following to promote large scale adoption of CFC by fish farmers to increase fish production and thereby their socio-economic conditions:

- More number of knowledge building activities like meetings, discussions, mass media, etc. are to be planned and conducted by fisheries extension agencies to increase knowledge and thereby adoption of recommended CFC practices.

- Economic benefits of CFC need to be vividly highlighted to convince fish farmers to adopt CFC.

- Cosmopolite methods and channels like exposure visits, study tours, etc. need to be organized by the concerned extension agencies.

- More number of younger fish farmers need to be trained in CFC. 


\section{REFERENCES}

Anonymous. (1996). Statistical Handbook, Directorate of Economic and Statistics, Government of Assam. Guwahati, Assam. pp. 23.

Bhaskaran, C. (1976). A Study of sociometric identification of opinion leaders and their characteristics in a progressive and non progressive village in Kanyakumari district of Tamilnadu , M.Sc.,(Agri.) Thesis (unpub.), Bangalore, University of Agricultural Sciences.

Biswas, A., S. K. Acharjee, and M. A. Haque, (1991). Adoption of composite fish culture in the context of some psychological orientation. Environment and Ecology, 9 (3), pp. 661-663.

Bose, J. C. (1989). A study on consequences in adoption of fish culture practices. M. Sc. (Agri) Thesis, Coimbatore, Tamil Nadu Agricultural University,

Das, P., M. A. U.Bhaumic, , P. K. Pandit, B. Ray, and S. K. Mondal, (1987). Some variables contributing to the adoption of fish culture innovation. Proceedings of the Indian Fisheries Forum, Mangalore, College of Fisheries, pp. 4,467-4,470.

Ghosh, S., A.Haque, and A. Biswas, (1993). Farmer's knowledge and extent of application of composite fish culture technology. Environment and Ecology, 11, pp. 926-929.

Haque, M. A. [1979]. Adoption of recommended species of fish in composite fish culture, In: G. L. Ray, (Ed.). Management Development for Farmers, New Delhi, Mittal Publications, pp. 99-125.

Haque, M. A. (1981). Study of some factors related to the adoption of recommended species of fish in composite fish culture. Ph. D. Thesis (Unpublished), Kalyani (West Bengal), Department of Agricultural Extension, Bidhan Chandra Krishi Viswavidyalaya

Haque, M. A. and G. L. Ray, (1983). Factors related to the adoption of recommended species of fish in composite fish culture. Indian Journal of Extension Education, 19, pp. 7483.

Haque, M. A. and G. L. Ray, (1985). Adoption of recommended species of fish in composite fish culture - Some useful research findings. In: Agricultural Extension,

Communication Centre, Kalyani (West Bengal), Bidhan Chandra Krishi Viswavidyalaya, pp. 25-36.

Meeran, N. M. (1983). A study on adoption behaviour of fish farmers. M. Sc. Thesis, Madurai, Agricultural College and Research Institute.

Praveen, T. (1993). A study on the constraints in adoption of fish culture as perceived by fish farmers of Nellore district of Andhra Pradesh. M. Sc. Thesis, Extension Education Institute, Hyderabad, Andhra Pradesh Agricultural University,

Rogers. E. M. (1987). Diffusion of innovations. New York, The Free Press.

Singh, Y. K. (1964). A study of communication network in sequential adoption and key communication. Ph.D. Thesis (Unpub.) Division of Agricultural Extension, New Delhi, Indian Agricultural Research Institute.

Singh, R. (1992). Study on constraints in the functioning of milk producers' cooperative societies in Western Uttar Pradesh. Ph. D. Thesis, Karnal, National Dairy Research Institute.

Siddaramaiah, B. S. and K.Jalihal, (1983). A scale to measure extension participation of farmers. Indian Journal of Extension Education, 19, pp. 74-77.

Sontakki, B. S. (1989). Possession and use of farm implements by the farmers of Belgaum district. M. Sc. Thesis, Dharwad, University of Agricultural Science.

Supe, S. V. (1969). Factors related to different degrees of rationality in decision making among farmers. Ph.D. Thesis (Unpub.) Division of Agricultural Extension, New Delhi, Indian Agricultural Research Institute.

Supe, S. V. and S. N. Singh, (1969) Economic motivation scale, risk preference scale and scientific orientation scale. In: K. N. Singh, S. N. Singh, and M. R. Lokhande, (Eds.), Measurement in extension - research instruments developed at IARI (1963 - 1972), Division of Extension, New Delhi, Indian Agricultural Research Institute. 
Trivedi, G. (1963), Measurement of socio-economic status in rural farmer families, Ph.D. Thesis (Unpublished), Division of Agricultural Extension, New Delhi, Indian Agricultural Research Institute. 